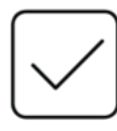

PERAET 2021

International Scientific Conference «PERISHABLE AND ETERNAL: Mythologies and Social Technologies of Digital Civilization-2021»

\title{
THE DECLINE OF EUROPE DOCTRINE IN RUSSIAN RELIGIOUS PHILOSOPHY
}

\author{
Vyacheslav T. Faritov (a)*, Ilya V. Demin (b) \\ *Corresponding author
}

(a) Samara State Technical University (SSTU), Samara, Russian Federation, vfar@mail.ru

(b) Samara University, Samara, Russian Federation, ilyadem83@mail.ru

\begin{abstract}
The article dwells on the place and role of the concept of the decline of Europe in Russian religious philosophy on the basis of a comparative analysis of the doctrines of I. V. Kireyevsky and K. N. Leontiev. Using the methods of philosophical comparative studies and historical and philosophical research, the authors reveal the cultural and linguistic features of the discourse of two representatives of Russian conservatism. The article pays the main attention to the problem of place in the Russian conservative thought, the ideas of the decline of Europe and the European pseudomorphosis of Russian culture. After performing the analysis, the authors conclude that in the doctrine of I. V. Kireyevsky the ideas of the death of the European world and the pseudomorphic influence of Western civilization on Russian culture go back not to the heritage of European philosophy, but to the patristic tradition of the Eastern Church. On the contrary, according to the authors, in the doctrine of K. N. Leontiev, these ideas are largely refracted through the prism of the philosophical ideas of F. Nietzsche. The article argues that the K. N. Leontiev's views on the problem of the future of Russia are more pessimistic than the views of I. V. Kireyevsky. The authors reveal the connection between the pessimistic position of K. N. Leontiev with the event of the crisis of European metaphysics and culture. The article substantiates the thesis that the pessimistic views of O. Spengler were anticipated in many aspects by K. N. Leontiev.
\end{abstract}

2357-1330 @ 2021 Published by European Publisher.

Keywords: Decline of Europe, I. Kireyevsky, K. Leontiev, Russian religious philosophy 


\section{Introduction}

More than a hundred years passed since "The Decline of Europe" by Spengler (2000) was published. Since that time, the statement about the completion of European civilization has moved from the sphere of philosophical speculation into the field of sociological forecasts supported by statistics. In just one century, Spengler became a "prophet". However, the very idea of the destruction of Europe is no less Russian than German, even to a greater extent and primarily more Russian than German. Before the publication of Spengler's book, this idea had already been presented in the works by N. Ya. Danilevsky and K. N. Leontiev. We find close representations even earlier, in the doctrines of the Slavophiles.

\section{Problem Statement}

The rise and development of Russian philosophy in many of its key points was influenced by the European thought just as the development of European philosophy is associated with the heritage of ancient thought. At least, these are the generally accepted views in historical and philosophical research. Such views are based, in turn, on the concept of the linear nature of the historical process, the subject of which is humanity as a whole. But this model turns out to be extremely unproductive in case of the development of Russian religious philosophy. For this philosophy, by its definition, cannot be anything other than a philosophical comprehension of the Orthodox Church doctrine and the content of Orthodox culture (Bykova, 2019; Horujy, 2019; Stoeckl, 2019). Otherwise, the very term "Russian religious philosophy" will turn out to be just an empty concept, hiding something completely different under it. The first significant attempts to create Russian religious philosophy are the works of those thinkers who were called "Slavophiles". This task determines the task characteristic of the Slavophilism representatives to dissociate from the heritage of European philosophical thought. Dissociation, in its turn, does not exclude, but, on the contrary, presupposes the influence, a certain degree of assimilation and even captivity, enslavement by Western philosophy (Apressyan, 2020). Otherwise, there would be nothing to become free of. Thus, the classics of Slavophilism develop the concept of a dying Europe and the allogeneity of European influence on Russian culture. Much later, at the beginning of the twentieth century, O. Spengler will write about the "European pseudomorphosis of Russian culture".

\section{Research Questions}

1) What is the specificity of understanding the relations between Russia and Europe in the doctrine of I. V. Kireyevsky?

2) What is the specificity of the transformation of views on Russia and Europe in the doctrine of K. N. Leontiev?

\section{Purpose of the Study}

The present research is not aimed at proving or refuting the truth of the very idea of the decline of European civilization. The focus of attention is exclusively on the place of the doctrine of the end of the Western world in the history of Russian philosophical thought. In this case we should mention the 
existence of alternative approaches. Thus, an authoritative Polish researcher claims that classical Slavophilism expresses the ideology of the old Russian nobility, defending the selfish interests of their class (Walitsky, 2019, p. 220).

It does not mean that, contrary to the Marxists, we intend to reduce all the diversity of Russian religious philosophy exclusively to Orthodox sources (this is what Walitsky (2019) reproaches Sergei Horujy for). Our purpose is to trace the genesis of the ideas of the decline of Europe and the European pseudomorphosis of Russian consciousness, taking into account the complexity and multidimensionality of the problem. Social, economic, as well as psychological factors are the soil on which certain ideas grow. But the soil is not the source of ideas and it does not determine the content of the doctrines. Ideas are born of other ideas and give rise to other ideas. To analyze this complex network of intersections, mutual influences, reveal the polyphonic or symphonic nature of the organization of heterogeneous material is the nature of the approach implemented in this research.

\section{Research Methods}

The research is based on the idea of synthesis of various methods and approaches. First of all, the study widely uses the methodological principles and settings of comparative analysis. The priority position of the comparative historical method is due to the fact that the study involves a comprehensive comparative analysis of doctrines related to different fields of knowledge, different eras and cultures.

\section{Findings}

\subsection{Russia and Europe in the doctrine of Ivan Kireyevsky}

The historiosophical concept of one of the founders of Slavophilism is built on the basis of the opposition between Russia and Europe. The image of Europe is constituted as a "negative other" in relation to Russian culture. Both members of the opposition are endowed with mutually exclusive characteristics, according to the principle: if Russia is $a$, then Europe is $b$, where $a$ is opposite to $b$. The situation, however, is complicated by the fact that at the time of the rise and development of Slavophiles' ideas, one of the members of the opposition mixed with the other in such a way that distinguishing between $a$ and $b$ becomes a very difficult mental task. As a result of Russia's assimilation of the features of European civilization, Russia is divided into two opposite elements: old and new Russia. Only old Russia acts as a direct antithesis to Europe. In the new Russia, only traces of this once defining character of Russian culture have survived. Already on the first page of his manifesto Kireyevsky (2015) introduces the concept of a trace, which in the future will determine the entire course of his reasoning (p. 5). Thus, the opposition, constitutive for the Slavophil historiosophy, is significantly complicated. The essential character of Russia moves into ancient times, whereas in the present, only traces of this substantial beginning could be found. These traces make up the soul, the "inner composition" of a Russian, while the outer character has already been transformed under the influence of European Enlightenment. Thus, it follows that the opposition between old and new Russia is built on the basis of a fundamental philosophical opposition of internal and external, which, in its turn, serves as the basis for constructing 
such oppositions as soul and mind, unconscious and consciousness. The peculiarity of the new Russia is that its external is not an expression of its internal. Accordingly, those principles that for Russia constitute only the outer side of its character, for Europe express the very root, the very nature of its existence. By the XIX-th century, the one-sided and therefore dead-end nature of the direction chosen by Europe had been fully revealed. Since there is nothing else in the foundation of Western civilization, it can only resign itself to the fact and accept the inevitable reality: the historical and cultural potential of Europe has been exhausted.

In this situation, Russia finds itself in a more advantageous position: in the deep foundation of Russian culture there is still unrealized creative potential, which the West no longer has. The very traces that Kireyevsky sees through the external structure of Russia transformed by Western influence indicate this internal potential of Russian culture.

The one-sided irrationalism only leads to an aggravation of the crisis. According to Kireyevsky, there are opportunities for new principles of philosophy in Russia. The Russian thinker sees the source of these possibilities in the heritage of the Eastern Fathers of the Church, which has not yet revealed its philosophical potential. European philosophy, like European culture in general, has Christianity as one of their sources. But Christianity penetrated Europe only in a single, most rationalized and one-sided form, the form of the Roman Church. The theological heritage of the Eastern Church was not assimilated by European thought.

Liberation from European influence is a necessary condition for the emergence in Russia of an original philosophical thought based on those principles that were not perceived and implemented by the thought of the West. The need for the emergence of this new philosophy is due to the fact that in Europe philosophical creativity has come to its logical conclusion, having completely exhausted its potential. Everything that the Western thought could produce has already been accomplished. Russia had to go through the school of Europe, had to assimilate the latest achievements and conclusions of Western philosophy in order to move more confidently in its own direction in the future. As mentioned above, similar ideas would be expressed by V. S. Soloviev and S. N. Bulgakov.

Similar trends of thought arose not only in Russia, but also in Europe already in the XIXth century, i.e. before the Spengler's treatise on the decline of Western civilization appeared. The Europeans themselves saw the crisis of European metaphysics (Balakleets \& Faritov, 2020). In Western philosophy, there were more and more insistent demands to search for other principles of thought, other foundations of culture. This circumstance served as the basis for the emergence in the research literature of the position according to which "even the Slavophiles, the heralds of the thesis about the allegedly radical identity of Russia, in essence, belonged to the pan-European ideological movement" (Walitsky, 2019, p. 20).

This position is not free from exaggeration. The thesis about the presence in German romanticism of similarities to the ideas of the Slavophiles is quite reasonable. But to deduce Slavophilism entirely from German sources and to deny the role of patristic heritage means to oversimplify the situation. Undoubtedly, German thinkers, primarily Schelling, influenced Kireyevsky (and later V. S. Soloviev and other representatives of Russian religious philosophy). But Schelling himself is already a representative of Western philosophy in the aspect of the crisis of the fundamental principles of European thought and 
culture in general. The very beginnings of the Western way of thinking should be sought in the Hegel's doctrine, and even better - in the systems of Kant, Leibniz, and Descartes. Schelling expresses the situation of the crisis of these principles and, accordingly, makes a turn towards the search for other foundations of philosophical thought. For this reason, the doctrine of Schelling contains coincidences with the way of thinking of the Eastern Fathers of the Church. In a crisis situation, European philosophy intuitively turns to those principles that were not perceived by it in the period of its own rise. These are the very principles that were already present in the patristic heritage of the Orthodox Church. Soloviev (1999) sums up his work "The Crisis of Western Philosophy" with the conclusion: "And here it turns out that these last necessary results of Western philosophical development affirm, in the form of rational knowledge, the very truths that had been affirmed in the form of faith and spiritual contemplation by the great theological doctrines of the East" (p. 177).

But even earlier than Soloviev, Kireyevsky recognized this coincidence of the latest results of Western philosophy with the heritage of the Eastern Fathers of the Church, it happened thanks to the influence of his wife, thanks to the influence of the elders (startsy) of Optina Pustyn (Koshelev, 1911, pp. 285-286).

The history of Kireyevsky's conversion is not only of biographical significance. Here is a prototype of the complex path of the rise and development of Russian religious philosophy: from Western, primarily German philosophical thought to the legacy of the Fathers of the Orthodox Church. This path has not yet been traversed. The philosophical potential of Orthodox theology has not been fully revealed. The main work was carried out in the direction, on the one hand, of assimilation of the latest achievements of Western philosophy, and on the other hand, of dissociation, overcoming this influence and the search for other principles of philosophical thinking. This bi-directional process characterizes the evolution of the doctrines developed by the majority of the outstanding representatives of Russian religious philosophy: from V. S. Soloviev to I. Ilyin, S. Frank and many others. There were both deviations and defeats on this path. There were also victories and progress (rethinking of the Russian theology path by Florovsky (2006)). I. V. Kireyevsky stands at the very beginning of this path. And he, like most Russian religious philosophers, began his journey with a passion for German philosophy. However, this fact is not a sufficient basis for such radical and one-sided conclusions which A. Walitsky makes. The influence of Schelling's ideas on Kireyevsky should not be absolutized, just as the influence of the Optina startsy and patristic books should not be denied. In general, one should not try to reduce such a complex phenomenon as Russian religious philosophy to a single source (Smirnov, 2020).

Meanwhile, in Europe, the crisis of philosophy and culture is becoming increasingly obvious. Following the romantic doctrine of Schelling, the pessimistic philosophy of Schopenhauer appears; after Schopenhauer comes the doctrine of Nietzsche, who discovered that the value attitudes of the old Europe no longer contain any foundation. Finally, the crisis of European civilization becomes the main theme of Spengler's philosophical research. These events in the history of thought find their expression in Russian philosophy. Spengler's ideas were anticipated in Russia by K. N. Leontiev. 


\subsection{Transformation of views on Russia and Europe in the doctrine of Konstantin Leontiev}

Konstantin Leontiev consciously and openly confronts the main intentions of the Slavophiles' doctrines. The classics of Slavophilism proceeded from ideas about the cultural originality of pre-Petrine Russia and at the same time saw in this originality the most complete embodiment of universal values, potentially having universal significance (as opposed to the extreme one-sidedness and limitedness of Europe). Echoes of these views can be still traced in the idea of Pan-Slavism by N. Ya. Danilevsky (Faritov, 2019). Leontiev (2017) rejects such views in the most radical way. According to Leontiev (2017), "all-Slavism" is either an abstract concept or an amorphous, spontaneous and disorganized phenomenon: "When we think about all-Slavism, we get only some kind of amorphous, spontaneous, disorganized representation, something similar to the sight of distant and vast clouds, which, as they approach, can form the most diverse figures" (p. 5). Slavism per se cannot act as an organizing principle, since it is a mass, a material that needs a sculptor. An amorphous mass needs form, the "despotism of the idea". According to Leontiev (2017), for Russia, such an organizing principle is Byzantism.

Both the Slavophiles and Leontiev consider the culture of Russia after Peter's reforms a kind of repulsion point. Both Kireyevsky and Leontiev are moving towards the search for the opposite foundations of Russian culture. Thus, one of the constitutive elements of the Slavophiles' doctrines is the opposition Moscow-Petersburg. Moscow is the embodiment of the primordial traditions of patriarchal Orthodox Russia; St. Petersburg is a product of the penetration of alien principles of Western civilization into Russia. For Leontiev, this opposition is losing its significance. The thinker is looking for an antithesis to Western influence elsewhere.

Like Kireyevsky, Leontiev sought genuine faith in Optina Pustyn. He even took the monastic vows. However, this does not give us grounds to assert that Leontiev's doctrine is closer to "genuine Christianity" than the views of Kireyevsky, Dostoevsky, V. S. Soloviov or someone else. Trubetskoy (1995) notes that Leontiev "preaches some kind of white with horror, undoubtedly distorted faith".

At the same time, Leontiev deviated from historical Orthodoxy differently, in a different direction than the Slavophiles, and after them the "Sophians", did. V. Soloviev, P. Florensky, S. Bulgakov, and the Trubetskoy brothers follow in their religious philosophy the direction set by the classics of Slavophilism. Ascending to A.S. Khomyakov, the idea of collegiality is refracted in various ways in the ideas of these thinkers, acting as one of the central points of their philosophical views. Leontiev is moving in a fundamentally different direction. He opposes the assertation of heterogeneity and inequality at any cost to the doctrine of total unity, of the synthesis of East and West. Instead of the ideal of all-pervading love he speaks about the need for violence and despotism as conditions for the "blossoming complexity" of culture. Thinking this way, Leontiev shows such a consistency that it turns into one-sidedness, close to fanaticism. But this one-sidedness highlights in contrast the one-sidedness of the mainstream of Russian religious philosophy. Perhaps, without Leontiev's extreme radicalism, it would not have been so easy to discern this different one-sidedness of Russian philosophical thought. After all, both the Slavophiles and the followers of V. Soloviov insist on the universal, "all-human" character of the path they affirm. Thanks to Leontiev's severe pessimism, we see that this universalism is imaginary, too ideal, romantic and dreamy. 
Because of this extreme one-sidedness, Leontiev is inferior to Nietzsche, with whom he is often compared. Nietzsche deliberately plays with mutually exclusive positions, as a result, the extremes are neutralized (however, not all Nietzsche's "followers" notice this and often become the victims of one or another one-sided point of view, which Nietzsche himself brought to the point of self-mockery and selfdeprivation). Leontiev affirms one extreme point of view and follows it. The consequence of this position is the linearity and one-dimensionality of philosophical thinking. But this one-pointedness, as we have already said, fulfills a compensatory function in the history of Russian religious philosophy. It shows that Russian philosophy is moving, albeit in a different, but not less extreme and one-sided direction. Therefore, in our opinion, it is not entirely correct to reduce Leontiev's significance to the role of only "the spokesman for the ideas of degenerating Slavophilism" (Lossky, 2000). Leontiev expressed and largely anticipated the crisis of Russian philosophical thought, which, in its attempts to free itself from Western influence or to make synthesis, is increasingly bogged down in alien forms (Mehlich, 2020; Murzin, 2019).

\section{Conclusion}

Summing up, we can conclude that in Leontiev's philosophy, the doctrine of the decline of Europe acquires a different semantic content than in the concepts of the Slavophiles. For Kireyevsky, the position of the exhaustion of Western culture acts as a condition of faith in the coming era of the integrity and originality of Russian culture. Leontiev's view on the decomposition of state forms in Europe leads to the conclusion that similar processes are inevitable in Russia.

We do not intend to argue that Leontiev's pessimistic predictions are closer to reality than the romantic aspirations of the Slavophiles. As a matter of fact, the task of philosophical research is not to predict the future, but to analyze the trends in the history of philosophical thought. Leontiev's position forces one to be more careful than, for example, Danilevsky or Spengler, and not to rush with the conclusions about the future health of one cultural organism on the basis of a deadly disease of another one. Moreover, this organism is infected with the same disease.

\section{Acknowledgments}

The article was prepared with the support of the Council for Grants of the President of the Russian Federation, project MD-2252.2021.2 "The political language of Russian conservatism: cultural and semiotic analysis".

\section{References}

Apressyan, R. G. (2020). Conceptualizing Morality in Early Modern Philosophy. Russian Studies in Philosophy, 58(2), 124-137. https://doi.org/10.1080/10611967.2020.1780835

Balakleets, N. A., \& Faritov, V. T. (2020). Fenomen granitsy v kontekste yevropeyskoy postmetafizicheskoy filosofii: K. Haushofer i F. Nietzsche [The phenomenon of the border in the context of European post-metaphysical philosophy: K. Haushofer and F. Nietzsche] Vestnik Tomskogo gosudarstvennogo universiteta [Tomsk State University Journal], 459, 61-67. https://doi.org/10.17223/15617793/459/7 
Bykova, M. F. (2019). Sergey S. Horujy and the Russian Religious Philosophical Tradition. Russian Studies in Philosophy, 57(1), 1-2. https://doi.org/10.1080/10611967.2019.1583491

Faritov, V. T. (2019). N. Ya. Danilevskiy kak filosof: granitsa i transgressiya v istorii. [N. Ya. Danilevsky as a Philosopher: Border and Transgression in History] Voprosy filosofii [Philosophy Problems]. 2, 107-116. https://doi.org/10.31857/S004287440003878-0

Florovsky, G. (2006). Puti russkogo bogosloviya [The paths of Russian theology]. Izd-vo Belorusskogo ekzarkhata

Horujy, S. (2019). The Concept of Neopatristic Synthesis at a New Stage. Russian Studies in Philosophy, 57(1), 17-39.

Kireyevsky, I. V. (2015). O kharaktere prosveshcheniya Yevropy $i$ yego otnoshenii k prosveshcheniyu Rossii [On the Nature of Education in Europe and Its Relationship to Education in Russia]. Obshchestvo pamyati igumenii Taisii.

Koshelev, A. I. (1911). Istoriya obrashcheniya Ivana Vasilievicha [The History of Ivan Vasilievich's Conversion]. Put'.

Leontiev, K. N. (2017). Vizantizm i slavyanstvo [Byzantism and Slavism]. Academichesky project.

Lossky, N. O. (2000). Istoriya russkoy filosofii [History of Russian Philosophy]. Svarog i K.

Mehlich, J. B. (2020). The Ambivalence of Legal Nihilism in Russia. Russian Studies in Philosophy, 58(1), 44-58. https://doi.org/10.1080/10611967.2020.1734388

Murzin, M. M. (2019). Gorky and Nietzsche: A Philosophical View of Man. Russian Studies in Philosophy, 57(5), 432-444. https://doi.org/10.1080/10611967.2019.1670543

Smirnov, A. V. (2020). Classical Eurasianism as a Post-Revolutionary Philosophy. Russian Studies in Philosophy. 58 (6), 522-534. https://doi.org/10.1080/10611967.2020.1868263

Soloviev, V. S. (1999). Filosofskoye nachalo tsel'nogo znaniya [Philosophical Beginning of Integral Knowledge]. Harvest.

Spengler, O. (2000). Zakat Evropy [The Decline of Europe]. Harvest, AST.

Stoeckl, K. (2019). New frontiers in Russian religious philosophy: The philosophical anthropology of Sergey S. Horujy. Russian Studies in Philosophy. 57(1), 17-39. https://doi.org/10.1080/10611967.2019.1545970

Trubetskoy, S. N. Razocharovannyy slavyanofil Disappointed Slavophile (1995) In. K. N. Leont'yev. Pro et Contra T. 1 [K. N. Leontiev. Pro et Contra. Vol. 1]. RHGA. Retrieved from http://russianway.rhga.ru/upload/main/07_trube.pdf

Walitsky, A. (2019). V krugu konservativnoy utopii. Struktura i metamorfozy russkogo slavyanofil'stva [In the Circle of a Conservative Utopia. The Structure and Metamorphoses of Russian Slavophilism]. UFO. 